\title{
PENGARUH TARI RODAD HADRAH TERHADAP RELIGIOSITAS REMAJA
}

\author{
Mufidatul Munawaroh' \\ Suroso \\ Program Studi Psikologi Profesi Universitas 17 Agustus 1945, Surabaya \\ Muhammad Farid \\ Fakultas Psikologi Universitas Darul Ulum, Jombang
}

\begin{abstract}
This study aims to know the effect of Hadrah Rodad Dance on adolescent religiosity. The subject of this study is male adolescents, who are 12 to 15 years old and being students of Islamic Junior High School (MTs) in Lamongan regency. There are 60 adolescents who are chosen, and they are grouped into two groups randomly. The first group consists of 30 adolescents as an experimental group. The second group consists of 30 adolescents as a control group. Type of this study is experimental research using pretest-posttest control group design. The research data is taken by using a religiosity scale. The data analysis technique used is analysis of covariance (ANACOVA) which is obtained by $F=67,744$ and $\mathrm{Sig} / p=0,00$. It means that there is a significant difference between the group of adolescent religiosity which gets the treatment of hadrah rodad dance (experimental group) and the group of adolescents who do not get the treatment of hadrah rodad dance (control group). After the groups have been given the treatment of hadrah rodad dance, there are different results of the groups. The religiosity average of the experimental group is 37,37 which is higher than the religiosity average of the control group, that is 5,76. The results of the study prove that the dance of hadrah rodad is an effective way to improve adolescent religiosity.
\end{abstract}

Keywords: Religiosity, Hadrah Rodad Dance

\begin{abstract}
ABSTRAK: Penelitian ini bertujuan untuk mengetahui pengaruh tari rodad hadrah terhadap religiositas remaja. Subjek penelitian adalah remaja laki-laki rerata usia 12 sampai 15 tahun, berstatus siswa Madrasah Tsanawiyah di Kabupaten Lamongan Jawa Timur yang berjumlah 60 yang dipilih secara random untuk kemudian dijadikan 2 kelompok, yaitu 30 remaja sebagai kelompok eksperimen dan 30 remaja sebagai kelompok kontrol. Jenis penelitian ini adalah penelitian eksperimen menggunakan pretest-postest control group design. Data penelitian diambil menggunakan skala religiositas. Dengan teknik analisis data Anakova diperoleh F $=671,744$ dan $\mathrm{sig} / \mathrm{p}=0,00$. Hal ini berarti terdapat perbedaan yang signifikan religiositas remaja pada kelompok yang memperoleh perlakuan tari rodad hadrah (eksperimen) dan kelompok remaja yang tidak mendapatkan perlakuan tari rodad hadrah (kontrol). Setelah diberikan perlakuan tari rodad hadrah, selisih rerata religiositas kelompok eksperimen $(37,37)$ lebih tinggi daripada kelompok kontrol $(5,76)$. Hasil penelitian menunjukkan bahwa tari rodad hadrah terbukti menjadi salah satu cara efektif meningkatkan religiositas remaja.
\end{abstract}

Kata kunci: religiositas, Tari Rodad Hadrah,

${ }^{1}$ Korespondensi mengenai artikel dapat melalui; muveedha@gmail.com 
Perkembangnya zaman dimana pergaulan remaja yang makin bebas memberikan rasa khawatir (Pristiwanti, 2013). Pergaulan bebas yang diadopsi remaja menyebabkan banyak sekali penyimpangan norma di Indonesia (Yetti, 2014). Indikasi, dapat dilihat dari semakin meningkatnya berbagai kasus kemerosotan akhlak remaja. Fakta menunjukkan bahwa remaja saat ini sudah berani melakukan perilaku-perilaku negatif secara terang-terangan di antaranya melakukan perilaku yang mengarah pada seks bebas di muka umum (Soraya, 2016; Marbun, 2017; Dzakwan, 2016), kekerasan dan pencurian (Sudarno, 2018; Puspita, 2018; Alamijaya, 2011), penggunaan narkotika dan obat-obatan terlarang atau narkoba (Simanjuntak, 2014; Harlina, 2017), pemukulan terhadap guru di Sampang Madura dan Kalimantan Barat (Taufiqurrahman, 2018; Akbar, 2018), dan menganiaya ibu kandung (Supriyanto, 2018).

Gambaran pergaulan remaja yang menyimpang dari norma di atas merupakan kemerosotan akhlak yang ditunjukkan remaja. Salah satu penyebabnya karena pengaruh masuknya budaya asing ke Indonesia. Pengaruhnya dapat dilihat melalui cara berpakaian remaja yang tidak sesuai dengan adat ketimuran sampai dengan cara bergaul yang bebas (Yetti, 2014). Pengaruh budaya modern yang negatif tersebut jika tidak diimbangi oleh kuatnya religiositas, maka kehidupan remaja akan hancur terkikis akibat merosotnya akhlak (Siswanto, 2007; Sari, 2013).

Perilaku-perilaku kemerosotan akhlak remaja yang tergambar di atas sudah menjadi masalah sosial yang hingga sekarang belum dapat diatasi secara tuntas oleh bangsa ini. Selama ini, banyak penelitian yang mengkaji kemerosotan remaja, namun belum ada yang dapat memberikan solusi berupa perlakuan nyata agar kemerosotan remaja dapat diatasi. Adanya kemerosotan nilai keagamaan diduga menjadi penyebab adanya kejadiankejadian tidak menyenangkan bagi masyarakat umum yang dilakukan remaja (Hidayat, 2015).

Remaja membutuhkan religiositas dalam kehidupan sehari-hari, seperti kebutuhan untuk keselamatan, cinta kasih, dan kebutuhan akan datangnya kematian (Thouless, 2000). Kebutuhan-kebutuhan tersebut dipercaya akan diperoleh dengan cara meningkatkan keimanan dan kepercayaan kepada Tuhan. Jika individu memiliki tingkat religiositas tinggi maka pengendalian diri, resilience dan moralitasnya bagus serta tingkat melakukan pelanggaran menjadi rendah (Listiari, 2011; Reza, 2013; Purnamasari, Syafe'i \& Komariah, 2014). Bentuk keimanan dan kepercayaan kepada Tuhan serta kecintaan kepada sesama makhluk tergambar dalam tari rodad hadrah yang merupakan tradisi dikalangan masyarakat Muslim. Tradisi memainkan tari rodad hadrah ini dilakukan dalam acara-acara keagamaan sebagai bentuk pujian dan sanjungan kepada Allah dan Rasul-Nya.

\section{Religiositas}

Religiositas merupakan internalisasi nilai-nilai agama dalam diri seseorang. Internalisasi disini berkaitan dengan kepercayaan terhadap ajaran-ajaran agama baik di dalam hati maupun dalam ucapan. Kepercayaan ini kemudian diaktualisasikan dalam perbuatan dan tingkah laku seharihari. Koenig, McCullough, dan Larson (2004) menyebutkan bahwa religiositas adalah tingkat pengabdian seseorang kepada Tuhan, komitmen dan partisipasi kepada lembaga agama serta perasaan kebermaknaan religi bagi kehidupannya. 
Sementara itu, menurut Ancok dan Suroso (1995), religiositas adalah sebuah sistem yang memiliki dimensi yang banyak dan diwujudkan dalam berbagai lingkup kehidupan baik itu yang tampak oleh mata manusia maupun yang tidak tampak oleh mata manusia dan diwujudkan dalam berbagai sisi kehidupan manusia. Selanjutnya, menurut Glock dan Stark (1970), religiositas adalah tingkat pengetahuan dan pemahaman yang menyeluruh bagi seseorang terhadap agama yang dianutnya. Religi atau agama menunjuk pada aspek formal yang berkaitan dengan aturan-aturan dan kewajiban-kewajiban, sedangkan religiositas menunjuk pada aspek religi yang telah dihayati oleh individu di dalam hati sehingga individu menjadi baik (Mangunwijaya, 1982; Kibuuka, 2005).

Religiositas seseorang akan meliputi berbagai macam sisi dan dimensi. Agama adalah sistem yang berdimensi banyak. Glock dan Stark (1965) membagi dimensi atau aspek religiositas menjadi lima, yaitu: (1) Dimensi keyakinan, (2) Dimensi praktik agama, (3) Dimensi pengalaman, (4) Dimensi pengetahuan agama, (5) Dimensi pengamalan atau konsekuensi. Koenig, dkk. (2001) mengklasifikasi religiositas seseorang menjadi tiga aspek, yaitu: (1) Organizational Religiousity, (2) NonOrganizational Religiousity, dan (3) Intrinsic Reigiousity. King \& Furrow (2004) juga mengklasifikasi religiositas seseorang menjadi tiga aspek, yaitu: (1) Organizational religiousity, (2) Non-organizational religiousity, dan (3) Intrinsic reigiousity.

\section{Religiositas Remaja}

Menurut Glock dan Stark (Ancok \& Suroso, 1995) bahwa individu yang memiliki religiositas tinggi akan tercermin dalam perilakunya. Remaja membutuhkan religiositas dalam kehidupan sehari-hari, seperti kebutuhan untuk keselamatan, cinta kasih, dan kebutuhan akan datangnya kematian (Thouless, 2000). Kebutuhankebutuhan tersebut dipercaya akan diperoleh dengan cara meningkatkan keimanan dan kepercayaan kepada Tuhan. Jika individu memiliki tingkat religiositas tinggi, maka pengendalian diri, resilience dan moralitasnya bagus serta tingkat melakukan pelanggaran menjadi rendah (Listiari, 2011; Reza, 2013; Purnamasari, dkk., 2014).

Masa remaja adalah sebagai masa transisi dari masa anak-anak ke masa dewasa, yang terdiri atas remaja awal (1215 tahun), remaja pertengahan (15-18 tahun), dan remaja akhir (18-21 tahun), merupakan masa akan beralihnya ketergantungan hidup kepada orang lain. Remaja mulai menentukan jalan hidupnya. Selama menjalani pembentukan kematangan dalam sikap, berbagai perubahan kejiwaan terjadi, bahkan mungkin kegoncangan (Sarwono, 2001; Kartono, 2010). Lingkungan sangat berpengaruh besar dalam pembentukan jiwa remaja. Bila remaja memasuki lingkungan pergaulan yang sehat, maka remaja akan mendapatkan dampak positif bagi perkembangan kepribadiannya terutama dalam religiositasnya.

Berdasarkan beberapa definisi diatas, dapat disimpulkan bahwa religiositas remaja adalah suatu gambaran keadaan dalam diri remaja yang mendorong remaja bertingkah laku dan bersikap sesuai dengan tuntunan agama yang diyakininya dalam hal ini membangun hubungan dengan Tuhan dan sesama manusia.

Hasil penelitian Sinha, Cnaan dan Gelles (2007) menunjukkan bahwa pemuda memandang agama sebagai sesuatu yang penting. Aktif dalam ibadah dan kegiatan keagamaan, serta partisipasi dalam kegiatan keagamaan dapat mengurangi perilaku berisiko yaitu: merokok, penggunaan alkohol, pembolosan, aktivitas seksual, penggunaan marijuana, dan depresi. Jika remaja memiliki keberagamaan yang bagus, 
diharapkan remaja nantinya mampu membendung dampak arus globalisasi yang menjurus pada perilaku negatif .

Aktualisasi kehidupan religi sering masih diwarnai tradisi-tradisi serta keyakinan dalam bentuk religiositas. Kepercayaan ini kemudian diaktualisasikan dan tercermin dalam perbuatan dan tingkah laku sehari-hari. Menurut Reusen (1992), tradisi adalah warisan atau norma, adat istiadat, kaidah-kaidah, harta-harta. Tradisi bukan suatu yang tidak bisa dirubah. Tradisi justru perpaduan dengan beragam perbuatan manusia dan diangkat dalam keseluruhannya.

\section{Tari Rodad}

Salah satu tradisi yang masih terus dilestarikan adalah tarian rodad hadrah. Seni tari rodad hadrah merupakan warisan budaya lokal yang dirintis oleh para alim ulama' pada masa lampau, hingga sampai saat ini masih berkembang dan mewarnai berbagai kesenian tradisional di Indonesia (Nurbaiti, Ismunandar \& Fretisari, 2016). Rodad hadrah juga merupakan satu kesenian tradisional yang cukup unik karena menggabungkan elemen tari dan musik (Nuruddin, 2015).

Setiap gerakan rodad terkandung nilainilai religiositas (Jazuli, 1994). Makna setiap gerakan yang dilakukan dan dilantunkan oleh perodad hadrah didalamnya terdapat nilai hablum minaallah dan hablum minannas, yaitu: (1) Rodad badan dengan mengikutsertakan tengokan (tolehan) kepala yang diserasikan dengan notasi irama rebana. Rodad ini mengilustrasikan bahwa sebagai makhluq, kita diwajibkan tidak hanya melihat dan memikirkan diri sendiri namun juga melihat dan memikirkan makhluq lain, (2) Rodad badan dengan tarian tangan. Rodad ini mengilustrasikan penulisan lafadz Allah Jalalah yang menunjukkan makna bahwa kita sebagai makhluq senantiasa mengingat Allah dan seakan-akan menulis lafadz Muhammad yang menunjukkan makna adanya rasa senang dan cinta kepada Nabi, (3) Keplok tangan/tepuk tangan dimaksudkan melahirkan rasa bahagia atas kehadiran Rosulullah saw yang diyakini beliau hadir pasa saat sejarah maulidnya dibacakan, (4) Sendekap dimaksudkan menunjukkan sikap pasrah kepada Allah, dan (5) Suara kecil dimaksudkan untuk bermunajat dan mengadu kepada Allah SWT dan memohon syafaat dari Rosulullah. (Nuruddin, 2015)

Seseorang yang memiliki religius tinggi menyadari akan keberadaan diri sebagai bagian dari komunitas sosial dalam menjunjung tinggi kedamaian, kesejahteraan dan keseimbangan diantara sesama dalam bentuk saling toleran, bekerjasama dan tolong menolong (Farid, 2011).

Seni rodad memiliki tabuhan musik rebana yang dipadukan dengan bacaan sholawat dapat disebut sebagai bagian dari terapi musik. Terapi musik berperan sebagai salah satu teknik relaksasi untuk memperbaiki, memelihara, mengembangkan mental, fisik, dan kesehatan emosi (Djohan, 2006).

Musik memiliki beberapa manfaat, yaitu: musik menutupi bunyi dan perasaan yang tidak menyenangkan, mempengaruhi pernapasan, mempengaruhi denyut jantung, mempengaruhi denyut nadi dan tekanan darah, mempengaruhi suhu badan, mempengaruhi rasa sakit, dan dapat menimbulkan rasa aman dan sejahtera (Djohan, 2006).

Di sisi lain, tari rodad juga terdapat unsur gerak menari. Menari merupakan cara ekspresi diri. Pada dasarnya, menari merupakan penggunaan gerak yang bisa bersifat menyembuhkan untuk memperbaiki kesehatan fisik dan mental seseorang atau bisa disebut sebagai terapi gerak. Terapi gerak adalah terapi aktivitas fisik yang dilakukan dengan cara berolahraga untuk melatih otot-otot tubuh seseorang agar sehat jasmani dan rohani (Saseno, 
2001). Menurut Kendhin (Setyanto \& Maliya, 2010), aktivitas fisik dapat dilakukan dengan menggerakan anggota tubuh yang menyebabkan pengeluaran tenaga yang sangat penting bagi pemeliharaan kesehatan fisik, mental, dan mempertahankan kualitas hidup agar tetap sehat dan bugar sepanjang hari.

Tari rodad hadrah, di samping memiliki manfaat juga mempunyai beberapa fungsi. Jazuli (1994) mengatakan bahwa tari rodad dalam kesenian Hadrah berfungsi sebagai media pendidikan yang dapat dilihat dari syair dan gerak tarinya. Syair dan gerak tari rodad hadrah mengandung beberapa nilai, yaitu: (1) Pendidikan karakter beriman dan bertakwa kepada Allah swt., (2) Pendidikan moral yaitu berakhlak mulia, dan (3) Pendidikan etika dapat dilihat dari sikap tubuh penari yang duduk bersimpuh dalam bergerak. Suatu keadaan sikap badan yang paling ideal dalam berkomunikasi, baik antar sesama maupun kepada Allah swt (Naruddin, 2015).

Tari Rodad dalam kesenian Hadrah juga memiliki fungsi sosial, yaitu nilai-nilai yang akrab dengan masyarakat seperti nilai-nilai Agama, moral, dan keindahan yang berlaku pada masyarakat tersebut. Seni menyandang fungsi sosial bersifat manusiawi, karena hakikat seni adalah untuk dikomunikasikan, berarti untuk dinikmati, ditonton, didengar atau diresapkan (Hadi, 2000; Jazuli, 1994). Tari rodad hadrah juga digunakan sebagai wadah interaksi sosial dalam masyarakat. Kebiasaan bersama dan keakraban masyarakat mampu terjalin lewat adanya kegiatan berodad ini. Menurut pendapat Fowler bahwa perkembangan religiositas remaja meningkatkan kemampuan remaja dalam mengambil keputusan yang berkaitan dengan perilaku moral (dalam Santrock, 2003).
Religiositas mengantarkan seseorang akan pentingnya menjalin hubungan dengan Tuhan (hablum minaallah) maupun dengan sesama (hablum minannas). Dalam religiositas tersebut terkandung nilai-nilai yang sama yang bisa kita dengar dan lihat pada setiap lantuan dan gerakan dalam tari rodad hadrah (Nuruddin, 2015).

Tari rodad dalam kesenian hadrah memiliki banyak fungsi dalam kehidupan masyarakat sehingga perlu dipelihara, dan dipertahankan. Fungsi tari rodad secara psikologis bisa dilihat dari syair dan gerak tarinya yang mengandung beberapa nilai religius. Lantunan syair-syair atau pujipujian yang diucapkan dengan penuh kekhusu'an dan kepasrahan oleh perodad seperti kata "lailaaha illaallah" dan bacaan sholawat kepada Nabi Muhammad, sikap perodad dalam gerakan tari rodad yang dinamis seperti berbaris (posisi duduk dan berdiri dengan lutut) dengan rapat kemudian menggerakkan badan kekanan dan kekiri serta menepuk kedua tangan yang didalamnya terdapat unsur kebersamaan dan kerjasama (team work), dan sikap tubuh penari yang duduk bersimpuh dalam bergerak yang merupakan suatu keadaan sikap badan yang paling ideal dalam berkomunikasi kepada Allah swt. maupun interaksi dengan sesama (Nuruddin, 2015). Pendapat tersebut dikuatkan oleh dewan ulama ISHARI Jawa Timur yang menyatakan bahwa berdasar sejarah dilakukannya hadrah yang didalamnya juga terdapat tarian rodad yang didalamnya terkandung nilai-nilai keagamaan dan sosial (Nuruddin, 2015).

Berdasar fenomena-fenomena yang tergambar di atas, maka menjadi hal penting dan urgent yang harus dicari solusinya oleh bangsa Indonesia agar kemerosotan akhlak remaja dapat diminimalisir atau bahkan dapat dihilangkan dengan meningkatkan religiositasnya. Peneliti berpandangan bahwa tari rodad hadrah menunjukkan 
dimensi psikologis yang berhubungan dengan religiositas karena itu peneliti tertarik mengadakan penelitian tentang pengaruh Tari Rodad Hadrah terhadap religiositas Remaja. Hipotesis penelitian yang diajukan dalam penelitian ini adalah tari rodad hadrah yang memuat lantuan syair yang berisi puji-pujian kepada Allah dan Rasul yang disertai iringan tabuhan rebana serta gerakan tari rodad dapat meningkatkan religiositas remaja.

\section{METODE PENELITIAN}

\section{Desain Penelitian}

Penelitian ini menggunakan pendekatan eksperimen dengan desain penelitian pretest-posttest control group design (Zinzer, 1984) yang diskematisasi sebagai berikut:

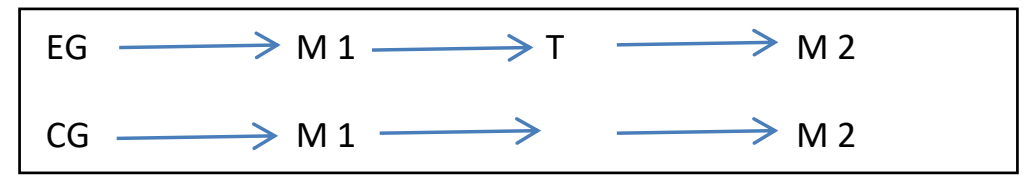

Gambar 1. desain penelitian pretest-posttest control group design

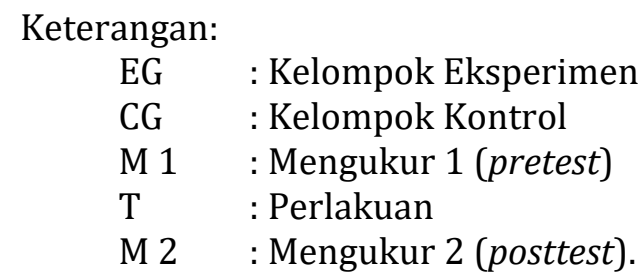

Penerapan desain di atas dalam penelitian ini adalah: (1) Memilih sampel secara random dari populasi untuk ditempatkan sebagai kelompok eksperimen (Experiment Group) dan kelompok kontrol (Control Group), (2) Kelompok eksperimen dan kelompok kontrol diberikan pretest skala religiositas remaja sebelum memperoleh perlakukan (Measurement 1), (3) Mengusahakan kedua kelompok tersebut dalam kondisi sama, kecuali adanya perlakuan tari rodad (Treatment) pada kelompok eksperimen sebanyak 16 pertemuan. Setiap pertemuan selama 1.5 jam (1 sesi) dan kelompok kontrol tanpa memperoleh perlakukan. Modul Uraian pelaksanaan seperti tergambar di modul pelatihan, (4) Setelah pemberian perlakuan kepada kelompok eksperimen berakhir, maka selanjutnya kelompok eksperimen dan kelompok kontrol diberi pascates religiositas remaja (Measurement 2).

Aplikasi atau tahap pretest-posttest control group design terangkum dalam tabel 1: 
Tabel 1: Aplikasi Atau Tahap Pretest-Postest Control Group Design

\begin{tabular}{|c|c|c|}
\hline Tahap & $\begin{array}{l}\text { Uraian } \\
\end{array}$ & Waktu \\
\hline 1. & $\begin{array}{l}\text { Sebar skala tingkat religisuitas (pretest) dan sesi } \\
\text { pertama sampai sesi ke-empat pemberian training } \\
\text { kepada kelompok eksperimen }\end{array}$ & 23 April 2018 \\
\hline 2. & $\begin{array}{l}\text { Sesi ke-lima sampai sesi ke-delapan pemberian } \\
\text { training kepada kelompok eksperimen }\end{array}$ & 26 April 2018 \\
\hline 3. & $\begin{array}{l}\text { Sesi ke-sembilan sampai sesi ke-duabelas pemberian } \\
\text { training kepada kelompok eksperimen }\end{array}$ & 30 April 2018 \\
\hline 4. & $\begin{array}{l}\text { Sesi ke-tigabelas sampai sesi ke-enambelas pemberian } \\
\text { training kepada kelompok eksperimen dan sebar skala } \\
\text { tingkat religisuitas (postest) }\end{array}$ & 2 Mei 2018 \\
\hline
\end{tabular}

\section{Subjek Penelitian}

Pengambilan sampel secara random, peneliti mencampur subjek-subjek sehingga semua subjek dianggap sama (Arikunto, 1998). Subjek penelitian yang terpilih sebagai responden penelitian diambil dari 2 gugus/sekolah yang berbeda dengan cara: (1) Memilih sampel atau cuplikan secara random sebanyak 60 remaja dari populasi yang berjumlah 314 remaja usia 12 sampai 15 tahun dengan rincian 30 remaja dari sekolah MTs Putra Putri Simo dan 30 remaja dari MTs Al-Muslimun kawistolegi, (2) Setelah ditentukan subjek penelitian sebanyak 60 remaja dari 2 gugus kemudian dibagi menjadi 2 kelompok. Kelompok pertama menjadi kelompok eksperimen dengan jumlah 30 remaja dan kelompok kedua dengan jumlah 30 remaja dijadikan kelompok kontrol.

Alasan memilih 2 gugus sekolah tersebut karena keduanya memiliki prestasi yang hampir sama dibuktikan dengan nilai akreditasi yang dimiliki sekolah dan prestasi siswa/siswinya. Apabila dicermati prosedur pengambilan sampel dalam penelitian ini secara skematis digambarkan sebagai berikut:

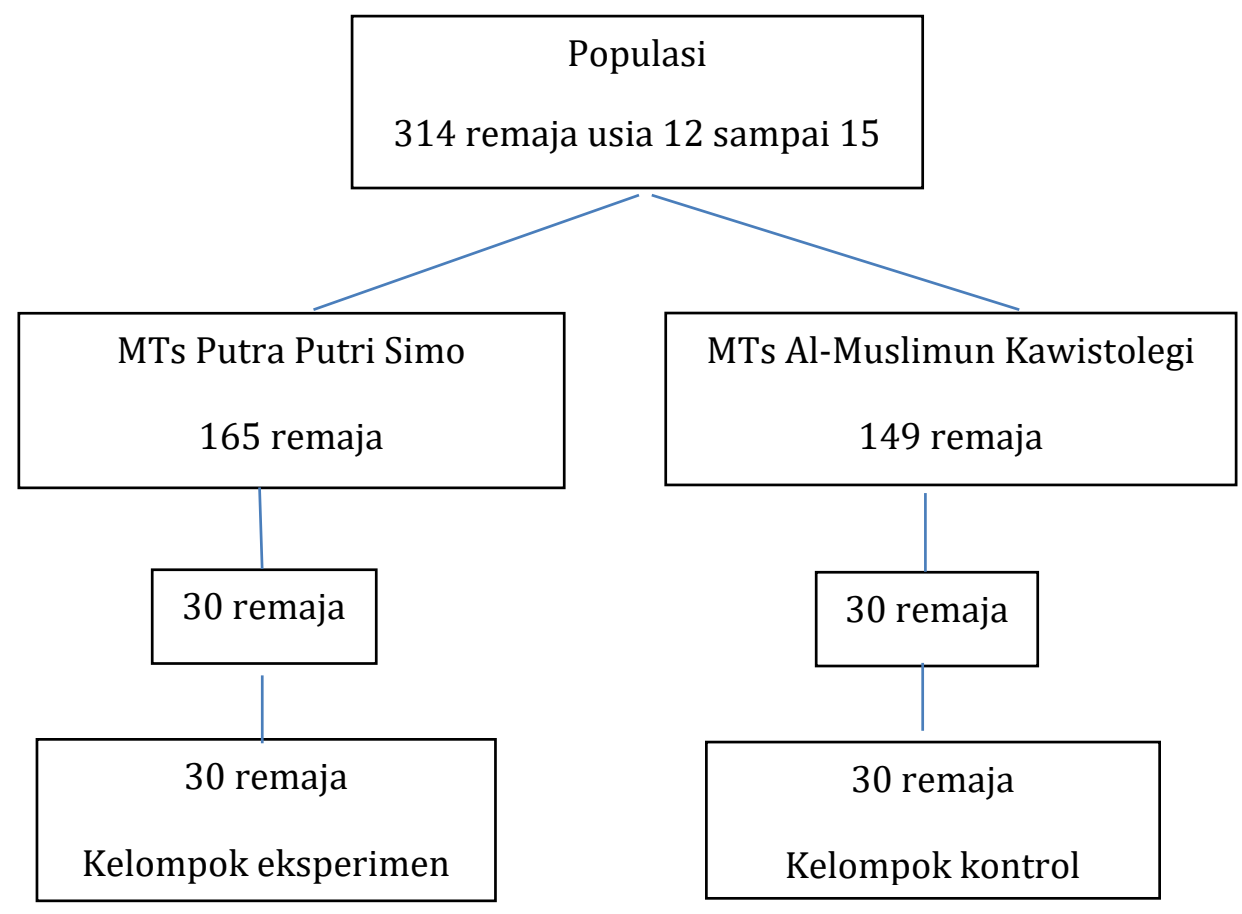

Gambar 2. Prosedur pengambilan sampel 


\section{Metode Pengumpulan Data}

Data penelitian tentang religioistas remaja diukur melalui skala religiositas yang disusun berdasarkan konsep Koenig, dkk (2004) meliputi: (1) Organizational Religiousity, berupa kesediaan remaja untuk turut serta terlibat secara langsung terhadap acara-acara keagamaan dan sosial kemanusiaan yang dilaksanakan oleh lembaga agama, (2) Non-Organizational Religiousity, berupa kesediaan remaja melakukan rutinitas menyediakan waktu dan tenaga untuk menjalankan ritual peribadatan, (3) Intrinsic Religiousity, berupa perilaku-perilaku remaja yang mengindikasi derajat kebermaknaan religi.
Skala religiositas terdiri dari 44 aitem dengan koeffisien korelasi aitem dengan skor total skala yang dikoreksi berkisar antara 0.275 - 0.642 dan reliabilitas Alpha sebesar 0.934 .

\section{Teknik Analisis Data}

Analisis yang digunakan untuk menguji hipotesis penelitian adalah anakova. Uji ini dimaksudkan untuk mengetahui perbedaan religiositas antara kelompok kontrol dan kelompok eksperimen.

\section{HASIL PENELITIAN}

Data penelitian dianalisis dengan Anakova, ditampilkan dalam tabel 2.

Tabel 2. Hasil Anakova religiositas Kelompok Eksperimen dan Kelompok Kontrol

\begin{tabular}{lccccc}
\hline Kelompok & $\begin{array}{l}\text { Rerata } \\
\text { prates }\end{array}$ & $\begin{array}{l}\text { Rerata } \\
\text { pascates }\end{array}$ & $\begin{array}{l}\text { Selisih Rerata } \\
\text { Skor Pra-Pascates }\end{array}$ & F Anacova & Sig./p \\
\hline Eksperimen & 89,90 & 127,27 & 37,37 & 671,744 & 0,00 \\
Kontrol & 92,07 & 97,83 & 5,76 & & \\
\hline
\end{tabular}

Tabel 2 menunjukkan bahwa hasil Anakova diperoleh $\mathrm{F}=671,744, \mathrm{sig} / \mathrm{p}=0,00$, berarti ada perbedaan skor postest antara kelompok eksperimen dengan kelompok kontrol setelah mengendalikan pengaruh skor prates. Temuan ini menunjukkan ada pengaruh pelatihan seni tari rodad hadrah setelah mengendalikan skor prates terhadap religiositas remaja antara kelompok eksperimen dan kelompok kontrol. religiositas kelompok eksperimen lebih tinggi dari pada kelompok kontrol, terbukti religiositas selisih rerata skor prates ke pascates kelompok eksperimen (rerata = 37,37) lebih tinggi daripada kelompok kontrol (rerata $=5,76$ ).

Hasil penelitian tentang perbedaan setiap dimensi religiositas remaja antara kelompok eksperimen dengan kelompok kontrol ditampilkan dalam tabel 3 :

Tabel 3. Hasil Anakova Dimensi religiositas Kelompok Eksperimen dan Kelompok Kontrol

\begin{tabular}{llccccc}
\hline \multicolumn{1}{c}{$\begin{array}{c}\text { Dimensi } \\
\text { religiositas }\end{array}$} & Kelompok & $\begin{array}{c}\text { Rerata } \\
\text { prates }\end{array}$ & $\begin{array}{c}\text { Rerata } \\
\text { Pascates }\end{array}$ & $\begin{array}{c}\text { Selisi Skor } \\
\text { pra-pascates }\end{array}$ & F Anakova & Sig. \\
\hline $\begin{array}{l}\text { Organizational } \\
\text { Religiousity }\end{array}$ & Eksperimen & 29,00 & 45,63 & 16,63 & 481,646 & 0,00 \\
\cline { 2 - 5 } $\begin{array}{l}\text { Non- } \\
\begin{array}{l}\text { Organizational } \\
\text { Religiousity }\end{array}\end{array}$ & Kontrol & 29,47 & 30,33 & 0,86 & & \\
\cline { 2 - 5 } $\begin{array}{l}\text { Eksperimen } \\
\text { Intrinsic }\end{array}$ & 25,30 & 30,47 & 5,17 & 8,478 & 0,00 \\
Religiousity & Kontrol & 27,20 & 30,33 & 3,13 & & \\
\cline { 2 - 5 } & Eksperimen & 35,60 & 51,17 & 15.57 & 466,138 & 0,00 \\
\hline
\end{tabular}


Tabel 3 menunjukkan: (1) Ada perbedaan dimensi Organizational Religiousity remaja ( $\mathrm{F}=481,646 ; \mathrm{sig} / \mathrm{p}=$ $0,00)$, antara kelompok eksperimen dengan kelompok kontrol setelah memperoleh perlakuan tari rodad hadroh. Dimensi Organizational Religiousity selisih rerata skor prates ke pascates kelompok eksperimen (rerata $=16,63$ ) lebih tinggi daripada kelompok kontrol (rerata $=0,86$ ). (2) Ada perbedaan dimensi NonOrganizational Religiousity remaja( $\mathrm{F}=$ 8,478: $\mathrm{sig} / \mathrm{p}=0,00$ ), antara kelompok eksperimen dengan kelompok kontrol setelah memperoleh perlakuan tari rodad hadroh. Dimensi Non-Organizational Religiousity selisih rerata skor prates ke pascates kelompok eksperimen (rerata $=$ 5,17) lebih tinggi daripada kelompok kontrol (rerata $=3,13$ ). (3) Ada perbedaan dimensi Intrinsic Religiousity remaja ( $\mathrm{F}=$ 466,138; $\mathrm{sig} / \mathrm{p}=0,00$ ) antara kelompok eksperimen dengan kelompok kontrol setelah memperoleh perlakuan tari rodad hadroh. Dimensi Intrinsic Religiousity selisih rerata skor prates ke pascates kelompok eksperimen (rerata $=15.57$ ) lebih tinggi daripada kelompok kontrol (rerata $=1,73$ ).

\section{PEMBAHASAN}

Tari rodad dalam kesenian hadrah terdapat unsur musik dan gerak. Seperti dalam pelantunan syair-syair disertai tabuhan rebana dan gerakan tarinya. Syair/sholawat yang dibaca dalam rodad menunjukkan kecintaan kepada Sang pencipta dan Rasul-Nya. Dengan membaca syair/sholawat dalam rodad hadrah, diharapkan subjek eksperimen akan ingat dan tunduk pasrah kepada Sang Kholiq.

Syair yang dibaca dalam rodad hadrah berbahasa Arab yang bersumber dari kitab Al-Barzanji. Merupakan sebuah kitab sastra yang terkenal di kalangan umat Islam yang menceritakan sifat-sifat nabi dan keteladanan akhlaknya. Lantunan syairsyair yang dibaca Hadi dan perodad memiliki kandungan makna yang besar. Cinta kepada Allah, Rasul dan sesama makhluk merupakan pesan utama dalam setiap syairnya (Mita, 2013).

Terdapat istilah konsentrasi dalam psikologis kognitif (Suharnan, 2005). Menurut peneliti, salah satu dimensi psikologis yang terdapat pada tari rodad hadrah ini adalah adanya unsur penyimakan/konsentrasi oleh perodad. Hasil pengamatan dan wawancara peneliti kepada subjek eksperimen menunjukkan bahwa jika subjek eksperimen tidak berkonsentrasi penuh, maka tidak mungkin subjek eksperimen bisa melakukan gerakan tari rodad, membaca syair/sholawat dan menyesuaikan dengan irama pukulan rebana secara bersama. Berkonsentrasi penuh, menyebabkan subjek eksperimen dapat mengingat Sang pencipta dan RasulNya. Saat subejk eksperimen membaca sholawat, membutuhkan tingkat konsentrasi yang tinggi untuk bisa menyatukan antara syair/sholawat yang dibaca dengan tabuhan irama pukulan rebana yang dibarengi dengan gerakangerakan rodad. Jika dalam berodad tidak memfokuskan pikiran pada syair/sholawat yang dibaca dengan diiringi gerakangerakan rodad dan disesuaikan dengan tabuhan rebana, maka tarian rodad tidak akan menjadi dinamis.

Aplikasi pelatihan tari rodad hadrah kepada subjek eksperimen menggunakan sholawat mukhut li tahtim. Hasil wawancara peneliti kepada subjek eksperimen, $7 \mathrm{di}$ antaranya mengatakan bahwa:"Pikiran menjadi tenang, sejuk dan perasaan saya bahagia saat membaca mukhut-nya." //"Tenang sekali. Rasanya saya tidak bisa menghentikan gerakan dan bacaan yang saya lakukan. Saya senang."//"Perasaan saya 
terasa damai."//"Rasanya bahagia membaca mukhut yang dibarengi dengan tariannya."

Dari sisi psikologis, tari rodad hadrah dapat meningkatkan ketenangan, juga kepuasan. Hasil wawancara peneliti kepada subjek eksperimen di atas menunjukkan bahwa mereka merasa senang dan bahagia saat melakukan tarian rodad hadrah karena dapat membuat mereka bahagia, sejuk dan perasaannya damai. Melalui penghayatan terhadap irama tabuhan rebana dan bacaan syair yang dibaca serta tarian rodad membuat munculnya perasaan-perasaan tersebut. Hasil penelitian ini memperkuat pendapat Umar (2018) bahwa dengan menyimak dan menghayati lagu dan atau irama tertentu dapat melembutkan jiwa yang keras, meluruskan pikiran yang selama ini sering bengkok, membersihkan, dan memutihkan hati yang selama ini kotor. Lantunan-lantunan syair kitab barzanji yang dibaca Hadi dan perodad dalam tari rodad hadrah begitu indah serasa menghipnotis sehingga mampu membawa manusia merasakan ketenangan jiwa dan tidak lagi memikirkan nafsu duniawi.

Rodad hadrah terdapat amalan-amalan mahabbaturrosul, ditambah bacaan sholawat hadrah dengan diiringi tabuhan rebana dan tepukan tangan perodad. Mahabbah merupakan istilah arab yang berarti mencintai secara mendalam, artinya dalam rodad hadrah perodad dibawa pada kondisi dimana subjek merasakan kecintaan yang besar kepada Rasul. Saat lantunan sholawat dibaca dan posisi badan menari, perodad melakukannya sampai pada kondisi dimana pikiran subjek cenderung lebih rileks dan fokus (Nuruddin, 2015).

Menurut peneliti, berdasarkan pengamatan dan wawancara yang peneliti lakukan kepada subjek eksperimen bahwa tarian rodad hadrah juga merupakan usaha mengharmonisasikan elemen spiritual dan fisikal seorang manusia untuk mencapai kondisi ideal sehingga memudahkan terjadinya komunikasi dengan Sang Maha
Pencipta. Melalui tarian rodad hadrah, tubuh subjek eksperimen terhubung erat dengan pola gerak, napas, serta pikiran yang memungkinkan terjadinya keseimbangan, relaksasi, serta harmoni hidup lewat serangkaian latihan fisik berupa gerakan tari yang cermat dan penuh konsentrasi. Berikut ini ungkapan 6 subjek eksperimen setelah mengikuti treatment:

\section{"Saat saya melakukan tarian rodad hadrah, membuat pikiran saya fokus kepada bacaan yang di baca Hadi, sampai-sampai saya tidak tahu ada kejadian apa saja disekitar saya saat melakukan tarian rodad hadrah". Ada juga ungkapan 3 subjek penelitian selama mengikuti treatment: "Saat saya membaca sholawat/syair, saya menjadi ingat kepada Allah dan Nabi Muhammad saw. Ada perasaan bahagia saat saya menarikan tarian rodad hadrah."}

Ungkapan 9 subjek eksperimen di atas menunjukkan bahwa subjek perlu konsentrasi penuh dalam melakukan tarian rodad hadrah agar menghasilkan tarian yang dinamis dan juga dengan berkonsentrasi mereka dapat ingat kepada Allah dan NabiNya. Menurut peneliti, melalui tari rodad hadrah ini yang merupakan tarian religi, maka hati dan pikiran bisa terketuk membuka lebar-lebar perhatian kepada Tuhan melalui penyimakan syair dan lagu atau irama yang feminim yang ada dalam tarian rodad hadrah, karena bacaan syair yang merdu dan indah dapat menggiring seseorang membuka tabir-tabir yang selama ini ada disebabkan lamanya berpisah dengan Allah.

Rodad hadrah menggabungkan musik dan gerak tari, sehingga menghasilkan sebuah seni yang elok untuk dinikmati. Musik dan gerak tari ini dapat memberikan banyak manfaat. Dalam dunia psikologi, musik dan gerak digunakan sebagai terapi. Subjek eksperimen saat berodad 
menggerakkan seluruh badan mengikuti irama tabuhan rebana sembari membaca syai-syairnya. Saat subjek eksperimen menggerakkan badan akan menjadi berkeringat. Keringat yang timbul dari hasil aktivitas memberi banyak manfaat bagi kesehatan tubuh diantaranya badan menjadi sehat, meredakan stres, meningkatkan sistem kekebalan tubuh dan meningkatkan sirkulasi darah (Setyanto \& Maliya, 2010). Peneliti berpendapat bahwa irama musik tidak hanya dapat mempengaruhi mood seseorang, tapi juga dapat meningkatkan kualitas hidup dan dapat membantu meningkatkan kesehatan mental dan fisik seseorang. Melakukan terapi musik dapat meningkatkan kesehatan seseorang dalam beberapa hal seperti perkembangan emosional, fungsi kognitif, dan keterampilan motorik (Noya, 2019). Ungkapan 15 subjek penelitian setelah mengikuti proses treatment sebagai berikut://"Selesai saya melakukan pelatihan tari rodad hadrah, badan saya terasa sehat". // "Saya sudah tidak sering sakit setelah ikut pelatihan rodad"//"Saya merasa badan saya menjadi lebih baik setelah mengikuti latihan rodad".//

Hasil penelitian menunjukkan bahwa subjek eksperimen merasa kondisi fisik dan mentalnya menjadi bertambah bagus setelah mendapat pelatihan tari rodad. Terdapat dinamika psikologis yang juga menunjukkan ke arah pembentukan perilaku positif. Sikap perodad dalam gerakan tari rodad yang dinamis seperti tepuk tangan, rodad badan, duduk bersimpuh, mengeluarkan suara kecil, berbaris (posisi duduk dan berdiri dengan lutut) dengan rapat menempelkan badan sehingga tidak terlihat renggang dan melakukan gerakan tolehan kepala ke kiri dan ke kanan sambil bersendekap merupakan suatu keadaan sikap badan yang paling ideal dalam berkomunikasi, baik antar sesama maupun kepada Allah swt. Gerakan-gerakan dalam tari rodad mengilustrasikan bahwa sebagai makhluk, manusia diwajibkan tidak hanya melihat dan memikirkan diri sendiri namun juga melihat dan memikirkan makhluk lain dan juga senantiasa mengingat Allah SWT dan RasulNya sebagai wujud perilaku Organizational Religiousity, berupa kesediaan remaja untuk turut serta terlibat secara langsung terhadap acara-acara keagamaan dan sosial kemanusiaan yang dilaksanakan oleh lembaga agama, (2) NonOrganizational Religiousity, berupa kesediaan remaja melakukan rutinitas menyediakan waktu dan tenaga untuk menjalankan ritual peribadatan, (3) Intrinsic Religiousity, berupa perilaku-perilaku remaja yang mengindikasi derajat kebermaknaan religi.

Dalam psikologi agama dikenal istilah kesadaran agama (religious conscisussnes) dan istilah pengamalan agama (religious experience) (Daradjat, 1978). Menurut peneliti, kesadaran dan pengamalan agama di sini adalah aktifitas yang secara nyata dilakukan dengan cara menggabungkan unsur psikologis-fisiologis. Peneliti berpendapat bahwa tari rodad hadrah terkandung unsur kesadaran dan pengamalan agama, sehingga tari rodad dapat dipandang sebagai salah satu filsafat hidup yang dilatar belakangi ilmu pengetahuan yang universal yakni pengetahuan tentang seni pernafasan, anatomi tubuh manusia, pengetahuan tentang cara mengatur pernafasan yang disertai gerak anggota badan, bagaimana cara melatih konsentrasi, menyatukan pikiran, dan lain sebagainya. Jadi tari rodad merupakan sebuah sistem yang menyadarkan dan mengantarkan kita ke pengembangan diri, kesehatan lahir batin untuk mencapai kebahagiaan.

Sepuluh ungkapan subjek setelah mendapat pelatihan, di antaranya sebagai berikut: //"Saat melakukan gerakan tangan seakan-akan menulis lafadz Allah jalalah dan 
Muhammad membuat saya hanya mengingat Allah". //"Saat saya melakukan gerakan tarian tangan, saya melakukannya dengan pandangan mata ke telapak tangan saya, dan itu membuat saya mengingat Allah".

Hasil penelitian ini mendukung penelitian Abdullah, Bakar, dan Annuar (2013) bahwa rodad hadrah juga merupakan satu kesenian tradisional yang cukup unik karena menggabungkan elemen seni suara, musik dan tari. Seni musik merupakan salah satu elemen ciptaan manusia untuk menzahirkan perasaan dan emosi subjek. Mengingat Sang Kholiq wujud dari rasa yang ada saat melakukan rodad hadrah.

Dalam lintasan sejarah dunia Islam, seni musik dan berbagai seni yang lain dijadikan media dakwah untuk mengajak orang berhati lembut, berfikiran lurus, berperilaku santun, bertutur kata halus, dan menampilkan jati diri dan innerbeauty setiap orang (Umar, 2018). Sejarah membentuk ragam budaya yang menyebar menjadi salah satu media pemersatu masyarakat, terutama di Jawa. Tradisi lokal yang beraneka ragam mampu menghadirkan kekuatan tersendiri bagi masyarakat yang masih menganut dan memulyakan tradisi. Menurut peneliti, tari rodad hadrah merupakan budaya lokal dan salah satu bentuk kesenian yang dapat dijadikan sebagai media dakwah oleh masyarakat. Bacaan-bacaan dan gerakangerakan yang ada dalam tari rodad hadrah memberikan sentuhan tersendiri bagi seseorang sehingga religiositasnya menjadi semakin baik. Rodad hadrah menggabungkan musik dan gerak tari, sehingga menghasilkan sebuah seni yang elok untuk dinikmati. Musik dan gerak tari ini dapat memberikan banyak manfaat. Dalam dunia psikologi, musik dan gerak digunakan sebagai terapi.

Menurut peneliti, berdasar observasi dan wawancara yang peneliti lakukan kepada kelompok eksperimen memperoleh hasil bahwa irama dalam musik dan tarian rodad hadrah mampu menghadirkan nuansa religi bagi mereka. Syair dan gerak tarian rodad mengandung beberapa nilai religiositas yang dapat mengantarkan mereka akan pentingnya menjalin hubungan dengan Tuhan (hablum minaallah) maupun dengan sesama (hablum minannas).

Hasil temuan ini mendukung pendapat Jazuli (1994) bahwa tari rodad dalam kesenian hadrah berfungsi sebagai media pendidikan yang dapat dilihat dari syair dan gerak tarinya yang mengandung beberapa nilai, yaitu pendidikan karakter beriman dan bertakwa kepada Allah swt., pendidikan moral yaitu berakhlak mulia dan pendidikan etika. Nilai-nilai tersebut dibutuhkan oleh remaja dikarenakan masa remaja awal adalah masa dimana mulai muncul keraguraguan beragama. Hubungan manusia dengan Tuhan itu mudah, bahkan ada yang mengatakan sangat mudah, namun hubungan manusia dengan manusia lain tidaklah mudah atau sebaliknya. Pendapat peneliti bahwa ketika kita melukai seorang manusia tanpa kesengajaan, apa lagi dengan sengaja, Tuhan tidak akan mengampuni kita sebelum orang yang kita lukai memaafkan kita. Peneliti juga berpandangan bahwa banyak atau malah mungkin mayoritas dari manusia menyangka, mengira, mempercayai dan meyakini bahwa cinta kepada Tuhan dan sesama manusia sesuatu yang terpisah. Sesuatu yang tidak terkait antara dasar (hakikat) berhubungan dengan Allah dan sikap/akhlaq (pedoman) berhubungan dengan manusia maupun sebaliknya.

Menurut peneliti, mungkin saja di dunia ini masih banyak orang berasumsi bahwa aktifitas religiositas hanya terbatas pada dzikir-dzikir, shalat, puasa, dan ibadahibadah ritual lainnya, sementara sisi ibadah sosial diabaikan, namun asumsi seperti itu tentu saja tidak benar, karena ibadah sosial juga tidak kalah pentingnya dibandingkan ibadah ritual. Bahkan, tidak jarang karena mengabaikan ibadah sosial, ibadah ritual bisa menjadi tidak berarti. Agama 
menganjurkan manusia untuk melaksanakan tugas-tugas ibadah ritual namun juga melaksanakan tugas-tugas kemasyarakatan (Fathurrahim, 2017). Peneliti juga berpendapat bahwa banyak manusia sukses di dunia ini, mempunyai nama yang harum, disukai banyak orang, punya harta melimpah, jabatan/status yang tinggi dan lain sebagainya, padahal manusia tersebut belum tentu berhubungan baik dengan Allah, namun sebaliknya kita sering mendengar bahkan menjumpai langsung manusia yang mempunyai hablumminallah yang baik dan intens tapi hablumminannas kurang baik atau bahkan buruk, atau sebaliknya. Hasil penelitian menunjukkan bahwa subjek eksperimen memiliki tingkat religiositas yang tidak sama dalam ketiga aspek milik Koenig, dkk (2004). Ini membuktikan bahwa ketiga aspek religiositas tidak selalu berjalan bersama.

Religiositas merupakan kepercayaan terhadap ajaran-ajaran agama baik di dalam hati maupun dalam ucapan individu. Kepercayaan ini kemudian diaktualisasikan dan tercermin dalam perbuatan dan tingkah laku sehari-hari. Peneliti menilai seseorang yang religius biasanya memiliki empati untuk memahami pandangan dan perasaan orang lain, bersedia berbagi perasaan dengan orang lain dan memiliki kepedulian terhadap penderitaan orang lain. Salah satu ciri perkembangan religiositas remaja adalah berkembangnya perasaan sosial dalam kehidupan beragama. Remaja yang sangat religius kemungkinan besar memiliki nilai-nilai menolong orang lain dan bersedia menjadi sukarelawan daripada remaja yang religiositasnya rendah. Dalam ajaran rodad hadrah terdapat ajaran agar selalu menyebarkan kebaikan (Nuruddin, 2015).

Hasil penelitian menunjukkan bahwa subjek eksperimen setelah diberikan pelatihan tari rodad hadrah menunjukkan kesediaan lebih besar untuk turut serta terlibat secara langsung terhadap acara- acara keagamaan dan sosial kemanusiaan yang dilaksanakan oleh lembaga agama (Organizational Religiousity), kesediaan melakukan rutinitas menyediakan waktu dan tenaga untuk menjalankan ritual peribadatan (Non-Organizational Religiousity) dan melakukan perilaku-perilaku yang mengindikasi derajat kebermaknaan religi (Intrinsic Religiousity). Temuan penelitian ini mendukung penelitian Erzen (2008), melaporkan bahwa tarian religi (sufi) yang merupakan ritual sakral yang didalamnya terdapat unsur cinta kepada sang pencipta, diharapkan para pelakunya dengan cinta bisa menggapai kesempurnaan pada imannya, menghapuskan nafsu, ego dan hasrat pribadi dalam hidupnya serta menyebarkan kebaikan. Cinta kepada Tuhan dan sesama manusia tercermin dalam religiositas individu. Salah satu pengaruh religiositas kental ada dalam makna setiap syair dan tarian rodad dalam seni hadrah. Musik dan gerakan yang ada dalam tari rodad hadrah memiliki banyak manfaat bagi seseorang yang melakukannya.

\section{SIMPULAN DAN SARAN}

\section{Simpulan}

Berdasarkan hasil analisis data dan pembahasan, peneliti berkesimpulan bahwa religiositas sebagai wujud keberagamaan individu mempunyai fungsi mengembangkan individu menuju ke arah positif atau dengan kata lain religiositas harus dimiliki oleh remaja. Dalam tari rodad menunjukkan banyak dimensi psikologis yang mengarah pada peningkatan religiositas. Peneliti juga menyimpulkan bahwa tari rodad hadrah mempunyai pengaruh positif dalam meningkatkan aspek-aspek religiositas baik pada aspek Organizational religiousity, Nonorganizational religiousity, maupun Intrinsic religiousity. Hal tersebut sesuai dengan hasil penelitian yang membuktikan bahwa 
religiositas remaja dapat ditingkatkan dengan tari rodad hadrah.

\section{Saran}

Simpulan yang berdasarkan hasil penelitian yang baru saja dilakukan, maka dapat diajukan beberapa saran. Pertama: Kepada subjek disarankan untuk melakukan tari rodad hadrah yang sudah dilatihkan secara rutin/periodik dan menyebarluaskan kepada rekan yang lain agar dapat terus meningkatkan religiositas. Kedua: Kepada para ahli khususnya ahli dibidang psikoterapi, motivator dan trainer untuk menjadikan tari rodad hadrah sebagai salah satu alternatif materi pelatihan atau terapi untuk meningkatkan religiositas remaja.
Kegiatan atau terapi tersebut bisa melalui program-program khusus yang dirancang dalam bentuk pelatihan (training) tari rodad hadrah bagi remaja. Ketiga: Bagi lembagalembaga pendidikan dan keagamaan yang ingin meningkatkan religiositas remaja (siswa). Pemberian pelatihan tari rodad hadrah dapat dijadikan sebagai alternatif/diterapkan. Keempat: Bagi peneliti lain yang tertarik meneliti pelatihan tari rodad hadrah, dapat menghubungkan dengan variabel seperti motivasi belajar dan kontrol diri. Selain itu juga membuat variasi subjek penelitian yang lebih luas, seperti sekolah umum (bukan pesantren), tidak hanya pada remaja laki-laki, tetapi juga remaja perempuan.

\section{DAFTAR PUSTAKA}

Abdullah, M. I. N., Bakar, S. A.\& Annuar, T. M. (2013). Rodat: Budaya tradisi yang berevolusi. Wacana Seni Journal of Arts Discourse. Vol. 12. Diunduh pada 12 Mei 2018 dari http://www.myjurnal.my/public/ar ticle-view.php?id=76468. html.

Akbar, W. (2018, 8 Maret). Ditegur saat main HP di kelas, murid pukul guru dengan kursi. CNN Indonesia. Diunduh pada 2 Mei 2018 dari https://www.cnnindonesia.com/na sional/20180308171331-12281519/ditegur-saat-main-hp-dikelas-murid-pukul-guru-dengankursi.html.

Alamijaya, J. (2011, 9 September). Kasus pencurian oleh 9 remaja Kaltim. Diunduh pada 2 Mei 2018 dari http://kaltim.tribunnews.com/2011/ 09/30/bp2kb-berau-janjikanpendampingan-hukum.html.
Ancok, D. \& Suroso, F.N. (1995). Psikologi islami: Solusi Islam atas problemproblem psikologi. Yogyakarta: Pustaka Pelajar.

Daradjat, Z. (1978). Ilmu jiwa agama. Jakarta: Bulan Bintang.

Djohan. (2006). Terapi musik: Teori dan aplikasi. Yogyakarta: Galangpress.

Dzakwan, S. (2016, 27 Desember). . Pesta seks di kamar kos, enam remaja dgerebek warga. (2016, 27 Desember). Sindonews.com. Diunduh pada 5 Mei 2018 dari https://daerah.sindonews.com/rea d/1166200/174/pesta-seks-dikamar-kos-enam-remaja-digerebekwarga-1482837191.html.

Erzen, J. (2008). The dervishes dance: The sacred ritual of love. Journal Contemporary Aesthetics. Vol. 6. Diunduh pada 15 Maret 2018 dari $h t t p: / / h d l . h a n d l e . n e t / 2027 /$ spo. 7523862.0006.007. 
Farid, M. (2011). Hubungan penalaran moral, kecerdasan emosi, religiositas, dan pola asuh orang tua otoritatif dengan perilaku prososial remaja. (Disertasi tidak di publikasikan). Universitas Gadja Mada, Yogyakarta, Indonesia

Fathurrahim. (2017). Hablumminallah wa Hablumminannas. Diunduh pada 28 Maret 2019 dari

https://www.tongkronganislami.net /edisi-5-khutbah-jumat-terbaruhablum-minallah-wa-hablumminannas.

Glock, C.Y. \& Stark, R. (1970). Religion and society in tension. San Francisco: CA: Rand McNally.

Hadi, S. (2006). Seni dalam ritual agama. Yogyakarta: Tarawang Press.

Harlina, S. (2017, 7 Februari). 30 Remaja di Kendari konsumsi obat terlarang, 1 tewas. Detik News. Diunduh pada 3 Maret 2018 dari https://news.detik. com/berita/d-3642097/30-remajadi-kendari-konsumsi-obatterlarang-1-orangtewas?_ga $=2$. 112367426.719993241 .153824395 2-1772969808.1538243952

Hidayat, K. (2015, 6 Maret). Defisit moral bernegara. Koran Sindo. Diunduh pada 5 Februari 2018 dari https://nasional.sindonews.com/re ad/972858/18/defisit-moralbernegara-1425612622.html.

Jazuli. (1994). Telaah teoretis seni tari. Semarang: IKIP Semarang

Kartono, K. (2010). Patologi sosial 2: Kenakalan remaja. Jakarta: Rajawali

Kibuuka, H. (2005). Religiosity and attitudes on intimacy: Implications for the HIV/AIDS pandemic in central Uganda. Thesis. Duquesne University. Diunduh pada 10 maret 2018 dari https://dsc.duq.edu/etd/743.html.
Koenig, H.G; McCullough, M.E \& Larson, D.B. (2004). Handbook of religion and health. Oxford: Oxford University Press.

Listiari, E. (2011). Hubungan antara tingkat religiositas dan pengendalian diri pada remaja Tingkat SMA. Jurnal Psikologi Universitas Proklamasi 45 Yogyakarta. No.7. Diunduh pada 19 Maret 2018 dari

https://ejournal.up45.ac.id/index.p $\mathrm{hp} /$ psikologi/article/view/129.htm.

Mangunwijaya, Y. B. (1982). Sastra dan religiositas. Jakarta: Sinar Harapan.

Marbun, F. (2017, 15 April). Hamil tua, siswi SMA Ini tak boleh ikut UN. Sindonews.com. Diunduh pada 12 Mei 2018 dari

https://daerah.sindonews.com/ read/1197280/191/hamil-tuasiswi-sma-ini-tak-boleh-ikut-un1492199886.

Mita, S.V. (2013, Juni). "HADRA: Seni rebana Indonesia". Diunduh pada 15 Maret 2018 dari http://pesantren-budayanusantara.blogspot.co.id/2013/06/h adra-seni-rebana-indonesia.

Noya, A. (2019, 30 Januari). 3 Manfaat terapi musik untuk kesehatan Anda. Diunduh pada 29 Januari 2019 dari https://www.alodokter.com/3manfaat-terapi-musik-untukkesehatan-anda

Nuruddin, M. (2015). Al 'iqdu durori fi tarjamati sholawati 'ala nabi il ISHARI. Surabaya: Pimpinan Wilayah ISHARI Jawa Timur.

Pristiwanti, D. O. (2013, 19 Desember). Pergaulan bebas pada remaja di era globalisasi. Jufrnal Ilmiyah. Universitas Negeri Semarang. Diunduh pada 8 Maret 2018 dari http://www.academia.edu/113040 24/pergaulan-bebas-pada-remajadi-era-globalisasi 
Purnamasari, E., Syafe'i, M., \&Komariah, K. S. (2014). Pengaruh religiositas terhadap pelanggaran etika pada siswa Kelas XI MIA 4 dan XI IIS 2 SMA Negeri 14 Kota Bandung. Jurnal UPI TARBAWY. 1(2). Diunduh pada 12 Mei 2018 dari ejournal.upi.edu/ index.php/tarbawy/article/downlo ad/3771/2690.html.

Puspita, S. (2018, 27 Mei ). Remaja DV kerap lakukan pencurian koper di bandara sepulang sekolah. Kompas.com. Diunduh pada 28 Mei 2018 dari https://megapolitan.kompas.com/r ead/2018/05/27/17092131/remaj a-dv-kerap-lakukan-pencuriankoper-di-bandara-sepulang-sekolah

Reusen, V. (1992). Perkembangan tradisi dan kebudayaan masyarakat. Bandung: Tarsito.

Reza, I. F. (2013). Hubungan antara religiositas dengan moralitas pada remaja di Madrasah Aliyah (MA). Humanitas. 10(2), 45-58

Sari, L. M. (2013). Tingkat religiositas dengan kecemasan menghadapi menopause. Jurnal Online Psikologi. 01 (02). Diunduh pada 12 Mei 2018 dari http://ejournal.umm.ac.id/ index.php/jop/article/view/ 1664.html.

Sarwono, S.S. (2001). Psikologi remaja. Cetakan kelima. Jakarta: Rajagrafindo Persada.

Saseno, M.N. (2001). Relaksasi sebagai upaya mengurangi kecemasan menghadapi studi mahasiswa akper depkes magelang. (Tesis tidak dipublikasikan) Program Pasca Sarjana UGM, Yogyakarta, Indonesia
Setyanto, I. \& Maliya, A. (2010). Efektivitas terapi gerak terhadap perubahan tingkat kecemasan pada pasien skizofrenia di Rumah Sakit Jiwa daerah Surakarta. Journal UMS. Diunduh pada 23 Maret 2018 dari https://publikasiilmiah.ums.ac.id/h andle $/ 11617 / 3722$ ?show=full.

Sinha, J. W., Cnaan, R. A., \& Gelles, R. W. (2007). Adolescent risk behaviors and religion: Findings from a national Study. Journal of Adolescence. Vol. 30. Diunduh pada 23 April 2018 dari http://repository.upenn.edu/ spp_papers/54

Simanjuntak, R. A. Memprihatinkan, kasus penyalahgunaan narkoba oleh remaja. (2018, 16 Mei). Sindonews.com. Diunduh pada 15 Juni 2018 dari https://nasional. sindonews.com/read/924841/13/ memprihatinkan-kasuspenyalahgunaan-narkoba-olehremaja-1416114208

Siswanto (2007). Kesehatan mental: Konsep, cakupan dan perkembangannya. Yogyakarta: Andi

Soraya, R. (2016, 19 Mei).Heboh, beredar foto gadis SMA asyik berangkulan sambil menghisap rokok. Harian Indo. Diunduh pada 12 Maret 2018 dari http://www.harianindo.com/ ?s=Heboh $\% 2 \mathrm{C}+$ Beredar+Foto+Gadis +SMA+Asyik+Berangkulan+Sambil+ Menghisap+Rokok

Soraya, R.. (2016, 21 Januari). Bukannya risih, cewek cantik ABG ini malah keasyikan tubuhnya digerayangi 4 cowok. Harian Indo. Diunduh pada 12 Maret 2018 dari http://www.harianindo.com/?s=Bu kannya+Risih\%2C+Cewek+Cantik+ ABG+Ini+Malah+Keasyikan+Tubuhn ya+Digerayangi $+4+$ Cowok 
Sudarno, A. (2018, 2 Januari). Terlibat tawuran, siswa SMP tewas disabet celurit. Liputan6.com. Diunduh pada 12 Februari 2018 dari https://www. liputan6.com/news/read/3606293/ terlibat-tawuran-siswa-smp-tewasdisabet-celurit

Suharnan. (2005). Psikologi kognitif (Edisi Revisi). Surabaya: Srikandi.

Supriyanto, J. (2018, 24 Mei). Remaja ini tega menganiaya ibunya hingga bonyok lantaran tak diberi uang $\mathrm{Rp}$ 10 ribu. Tribunnews. Diunduh pada 15 Mei 2018 dari http://medan.tribunnews.com/ 2018/05/24/remaja-ini-tegamenganiaya-ibunya-hingga-bonyoklantaran-tak-diberi-uang-rp-10-ribu

Taufiqurrahman. (2018, 3 Februari). Penganiayaan guru oleh siswa di Sampang. Kompas. Diunduh pada 15 Mei 2018 dari https://regional. kompas.com / /read/2018/02/03/ $10041991 /$ penganiayaan-guruoleh-siswa-di-sampang-beginikronologinya
Thouless, R. H. (2000). Pengantar psikologi agama. Alih Bahasa: Machnun Husein. Jakarta: Raja Grafindo Persada.

Umar, N. (2018, 23 Mei). Menghayati sema'. Republika.

Umar, N. (2018, 24 Mei). Musik, puasa dan kelembutan jiwa. Republika.

Yetti. (2014, 19 November). Pengaruh budaya asing terhadap remaja Indonesia. Kompasiana. Diunduh pada 28 April 2018 dari https://www.kompasiana. com/yetti05/54f9373fa33311b77f8 b4877/pengaruh-budaya-asingterhadap-remaja-indonesia

Zinzer, O. (1984). Basic principles of experimental psychology. New York: Mc Graw Hill Book 
Mufidatul Munawaroh, Suroso \& Muhammad Farid 